\title{
Membangun Infrastruktur Kurikulum Prodi DKV Berbasis Core Busines Competencies
}

\author{
Dian Cahyadi ${ }^{1}$
}

\begin{abstract}
Abstrak
Menyitir dari pernyataan Presiden republik Indonesia dalam sambutan pada Kongres HIPIIS di Solo pada 9 agustus 2017 yang menyatakan bahwa ingin dunia pendidikan Indonesia menyesuaikan diri dengan inovasi teknologi yang kini sedang bekembang pesat, khususnya keilmuan desain grafis dan komunikasi visual sebagai contoh ekstrim yang sampaikannya. Oleh sebab itu lembaga-lembaga pendidikan tinggi mesti memiliki persiapan dalam wacana perkembangan global yang sangat melaju cepat. Prodi DKV perlu segera bersikap (flexiblities) melalui pernyataan tersebut melalui sejumlah penyesuaianpenyesuaian dalam bentuk revisi-revisi yang bersesuaian dengan kebutuhan dan tuntutan pasar global dengan mengacu pada KKNI dan SKKNI melalui rumusan-rumusan ideal dalam menghasilkan learning outcomes sebagai desainer global yang kompetitif dan berdaya saing tinggi melalui rancangan struktur kurikulum yang dibangun.
\end{abstract}

Kata Kunci: revisi kurikulum DKV, KKNI, SKKNI, desainer global.

\section{Pendahuluan}

"Jenis Pekerjaan apa sajakah yang bisa diperoleh sebagai kompetensi lulusan/learning outcomes ketika mahasiswa memilih menimba ilmu pada Program Studi Desain Komunikasi Visual ?"

Tentunya pertanyaan ini yang sering ditanyakan oleh orangtua mahasiswa yang menjadi tanggungjawab mereka atas nasib dan masa depan anak-anak mereka.

Desain Grafis merupakan bidang profesi yang berkembang pesat sejak Revolusi Industri (abad ke-19) saat di mana informasi melalui berbagai media semakin luas digunakan untuk mendukung perdagangan. Bidang Desain Grafis di dunia internasional juga dikenal dengan beberapa nama lain seperti Desain Komunikasi Visual, Desain Komunikasi, Komunikasi Visual dan Komunikasi Grafis. Di Indonesia istilah yang digunakan yaitu Desain Grafis atau Desain Komunikasi Visual (DKV).

Sebelum digunakan juga istilah Desain Komunikasi Visual, Desain Grafis ditinjau dari arti katanya: desain memiliki arti merancang atau merencanakan. Kata grafis sendiri mengandung dua pengertian: (1) Graphien (It.=garis, marka) yang kemudian menjadi Graphic Arts atau Komunikasi Grafis, (2) Graphise Vakken (bld=pekerjaan cetak) yang di Indonesia menjadi Grafika, diartikan sebagai percetakan. Jadi pengertian Desain Grafis adalah pekerjaan dalam bidang komunikasi visual yang berhubungan dengan grafika (cetakan) dan/atau pada bidang dua dimensi, dan statis (tidak bergerak dan bukan time-based image). Pengertian tersebut akhirnya berkembang karena meningkatnya kesadaran akan manfaat yang dapat dipetik dari keakuratan dalam penyampaian informasi pada masyarakat. Hal tersebut juga didukung dengan perkembangan teknologi informasi dalam bidang pengembangan perangkat lunak aplikasi desain grafis, internet, mobile dan teknologi digital lainnya.

Dengan demikian, secara khusus Desainer Grafis/Komunikasi Visual adalah seseorang yang mempunyai keahlian merancang solusi komunikasi visual melalui program identitas, informasi dan persuasi yang sesuai tujuan yang ditetapkan pemberi tugas kepada khalayak sasarannya dengan menggunakan media konvensional (berbasis cetak) maupun non konvensional (non cetak). Seorang Desainer Grafis/Komunikasi Visual mengemas informasi menjadi media visual yang dimengerti khalayak sasarannya. Desainer Grafis/Komunikasi Visual membuat konsep komunikasi grafis, merancang dan
1. Ketua Program Studi Desain Komunikasi Visual, Fakultas Seni dan Desain, Universitas Negeri Makassar, Jl.

Tamalate, Parang Tambung, Tamalate, Makassar, 90222, Indonesia

EMail

dian.cahyadi@gmail.com
Submitted:
Juli 2017
Accepted :
Juli 2017

JAS-PT

JURNAL ANALISIS SISTEM PENDIDIKAN TINGGI

ISSN 2580 - 5339

Volume 1

Nomor 1

JULI 2017

Hal $27-40$ 
menyelaraskan elemen-elemen desain sesuai dengan prinsip-prinsip desain. Untuk mencapai tujuan komunikasi yang diharapkan. [Kemenaker, 2016]

Permasalahan

Perkembangan teknologi telah memunculkan media baru yang lahan garapan baru para desainer grafis/komunikasi visual, sehingga memunculkan para spesialis di bawah bidang Desain Grafis/Desain Komunikasi Visual. Bidang Desain Grafis/Desain Komunikasi Visual tidak terbatas pada desain untuk media yang dicetak melainkan juga pada media digital yang berbasis waktu (time-based image).

Perkembangan teknologi informasi yang begitu pesat, memungkinkan diterapkannya cara cara yang lebih efisien untuk produksi, distribusi dan konsumsi barang dan jasa. Pada era informasi ini, jarak geografis tidak lagi faktor penentu dalam hubungan antar manusia atau antar lembaga usaha, sehingga dunia ini menjadi suatu kampung global atau disebut Global Village.

Kehadiran teknologi internet yang semakin pesat telah merubah kehidupan gaya masyarakat dan tuntutan pada kompetensi manusia. Pada masa kini, kehidupan manusia semakin bergantung pada sebuah komputer yang bagaimana merupakan media perangkat keras yang digunakan untuk mengakses dan juga mengolah sebuah informasi yang bermanfaat bagi para pembacanya.

Berdasarkan fenomena tersebut kemudian menjadi tantangan bagi institusi pendidikan tinggi sebagai lembaga pendidikan penyedia sumber daya manusia (SDM) dalam hal ini adalah PS DKV di Indonesia.

\section{Tinjauan Pustaka}

Menurut Iskandar Alisyahbana (1980). Teknologi telah dikenal manusia sejak jutaan tahun yang lalu karena dorongan untuk hidup yang lebih nyaman, lebih makmur dan lebih sejahtera. Jadi sejak awal peradaban sebenarnya telah ada teknologi, meskipun istilah "teknologi belum digunakan. Istilah "teknologi" berasal dari "techne " atau cara dan "logos" atau pengetahuan. Jadi secara harfiah teknologi dapat diartikan pengetahuan tentang cara. Pengertian teknologi sendiri menurutnya adalah cara melakukan sesuatu untuk memenuhi kebutuhan manusia dengan bantuan akal dan alat, sehingga seakan-akan memperpanjang, memperkuat atau membuat lebih ampuh anggota tubuh, pancaindra dan otak manusia. Sedangkan menurut Jaques Ellul (1967) memberi arti teknologi sebagai" keseluruhan metode yang secara rasional mengarah dan memiliki ciri efisiensi dalam setiap bidang kegiatan manusia"

Kemajuan teknologi adalah sesuatu yang tidak bisa kita hindari dalam kehidupan ini, karena kemajuan teknologi akan berjalan sesuai dengan kemajuanm ilmu pengetahuan. Setiap inovasi diciptakan untuk memberikan manfaat positif bagi kehidupan manusia. Memberikan banyak kemudahan, serta sebagai cara baru dalam melakukan aktifitas manusia. Khusus dalam bidang teknologi masyarakat sudah menikmati banyak manfaat yang dibawa oleh inovasi-inovasi yang telah dihasilkan dalam dekade terakhir ini.[lkhsan, 2016]

Presiden Republik Indonesia dalam sambutannya pada pembukaan Kongres ke-10 Himpunan Indonesia untuk Pengembangan IImu-IImu Sosial di Solo menyatakan keseriusannya dengan pernyataan dalam sambutannya terkait perubahan global, khususnya teknologi, dan berharap lembaga pendidikan tinggi serius melakukan persiapan agar Indonesia tidak jadi negara tertinggal dibandingkan negara lainnya. Berikut konten berita terkait hal tersebut

[Presiden Joko Widodo ingin dunia pendidikan Indonesia menyesuaikan diri dengan inovasi teknologi yang kini sedang bekembang pesat. Jokowi melihat dunia pendidikan di Indonesia sama sekali tidak berkembang. Hal itu dilihat dari jurusan pendidikan tidak ada yang berubah dari tahun ke tahun

"Kenapa di universitas kita dari dulu sampai sekarang hanya ada fakultas ekonomi, hukum, sosial politik, teknik. Padahal ini perubahan global sudah cepat sekali," ujar Jokowi ketika jadi pembicara dalam pembukaan Kongres ke-10 Himpunan Indonesia Untuk Pengembangan IImu-IImu Sosial (HIPIIS) di Solo, Jawa Tengah, Rabu (9/8/2017).

"Kenapa tidak ada fakultasi retail manajemen? Kenapa tidak ada fakultas resources management? Kenapa tidak ada fakultas green building?" lanjut dia.

Bahkan, Jokowi memberikan contoh ekstrem dalam hal pendidikan pengembangan dari desain grafis, yakni animasi. 
"Kenapa tidak ada fakultas animasi, nanti jurusannya meme juga bisa misalnya," lanjut Jokowi. Jokowi melanjutkan, dirinya tidak main-main dengan pernyataan itu. Perubahan global, khususnya teknologi, memang semestinya diikuti dengan persiapan agar Indonesia tidak jadi negara tertinggal dibandingkan negara lainnya.

"Jangan kita terlewatkan melakukan antisipasi ini sehingga tak bisa lagi mengejar perubahan yang ada dan akhirnya kita ini ditinggal," ujar Jokowi.] [Kuwado, 2017]

Menarik dari pernyataan presiden, tentunya menjadi perhatian dari lembaga-lembaga penyedia SDM bidang Desain Grafis dan Komunikasi Visual untuk segera menyikapi perubahan global agar lulusan dapat diserap oleh pasar internasional.

\section{Hasil Dan Pembahasan}

Pada Kepmen Ketenagakerjaan Republik Indonesia Nomor 301 Tahun 2016, tentang penetapan Standar Kompetensi Kerja Nasional Indonesia (SKKNI) kategori aktivitas profesional, ilmiah dan teknis lainya bidang Desain Grafis dan Komunikasi Visual. Bahwa era perdagangan bebas, baik dalam lingkup regional AFTA dalam kerangka Masyarakat Ekonomi ASEAN pada 31 Desember 2015 maupun dalam skala perdagangan bebas yang lebih luas dalam kerangka WTO, daya saing Sumber Daya Manusia (SDM) merupakan kunci untuk memenangkan persaingan. Era pasar bebas tidak hanya mengenai perdagangan barang dan jasa saja, namun juga menyangkut kebebasan mobilitas tenaga kerja antar negara. Situasi ini dapat menjadi peluang sekaligus tantangan, di satu sisi membuka kesempatan bekerja seluas-luasnya melintas negara dengan lebih mudah, di sisi lainnya persaingan tenaga kerja akan semakin tajam. Mempersiapkan SDM berdaya saing tinggi agar mampu berkompetisi secara global merupakan tantangan yang harus dihadapi. [Kemenaker, 2016]

Upaya menyiapkan SDM yang berkualitas sesuai dengan tuntutan pasar kerja tentunya dilakukan melalui pendidikan formal, nonformal, maupun informal. PS DKV dalam hal ini sebagai institusi pendidikan formal selama ini telah melakukan membangun struktur kurikulumnya yang terstruktur berdasarkan standar Kualifikasi Kurikulum Nasional Indonesia (KKNI). Dimana dalam penyusunan struktur kurikulum yang sesuai kualifikasi dan mengacu pada ketetapan Kerangka Kualifikasi Nasional Indonesia (KKNI) adalah kerangka penjenjangan kualifikasi sumber daya manusia Indonesia yang menyandingkan, menyetarakan, dan mengintegrasikan sektor pendidikan dengan sektor pelatihan dan pengalaman kerja dalam suatu skema pengakuan kemampuan kerja yang disesuaikan dengan struktur di berbagai sektor pekerjaan.

Hal ini merupakan perwujudan mutu dan jati diri bangsa Indonesia terkait dengan sistem pendidikan nasional, sistem pelatihan kerja nasional, dan sistem penilaian kesetaraan pada capaian pembelajaran (learning outcomes) nasional, yang dimiliki Indonesia untuk menghasilkan sumber daya manusia nasional yang bermutu dan produktif.

Secara umum KKNI diharapkan dapat melahirkan suatu sistem penyetaraan kualifikasi ketenagakerjaan di Indonesia dan memiliki peran yang ; a) komprehensif dan berkeadilan; b) memiliki jumlah jenjang dan deskripsi kualifikasi yang jelas dan terukur; c) bersifat lentur (flexible); d) pendorong program-program peningkatan mutu; e) mencakup pengembangan sistem penjaminan mutu yang memiliki fungsi pemantauan (monitoring) dan pengkajian (assessment) terhadap badan atau lembaga ; f) secara akuntabel dapat memberikan peluang pergerakan tenaga kerja; g) dapat menjadi panduan bagi para pencari kerja yang baru maupun lama; h) dapat menguatkan integrasi dan koordinasi badan atau lembaga penjaminan atau peningkatan mutu yang telah ada; i) diharapkan mencakup sistem Rekognisi Pembelajaran Lampau (RPL).

Konsep dasar KKNI tersebut mengandung makna kesetaraan dan pengakuan yang disepakati bersama antar pemangku kepentingan. Oleh karena itu KKNI harus dilengkapi dengan mekanisme dan aturanaturan yang diperlukan untuk mewujudkan kesetaraan dan adanya saling pengakuan. Dalam ranah pendidikan, dunia kerja dan keprofesian, mekanisme dan aturan-aturan tersebut mungkin telah ada dan disusun dengan baik, akan tetapi untuk ranah masyarakat luas hal ini memerlukan panataan yang komprehensif dengan memperhatikan unsur-unsur mutu, akuntabilitas dan integritas. [Kemenristekdikti, 2015]

\section{Level dan penjenjangan KKNI}

KKNI menyediakan sembilan jenjang kualifikasi yang ditetapkan dan dilakukan melalui pemetaan komprehensif kondisi ketenagakerjaan di Indonesia ditinjau dari sisi penghasil (supply push) maupun 
pengguna (demand pull) tenaga kerja. Diskripsi setiap jenjang kualifikasi juga disesuaikan dengan mempertimbangkan kondisi negara secara menyeluruh, termasuk perkembangan ilmu pengetahuan, teknologi dan seni, perkembangan sektor-sektor pendukung perekonomian dan kesejahteraan rakyat seperti perindustrian, pertanian, kesehatan, hukum, dan lain-lain, serta aspek-aspek pembangun jati diri bangsa yang tercermin dalam Bhineka Tunggal Ika, yaitu komitmen untuk tetap mengakui keragaman agama, suku, budaya, bahasa dan seni sebagai ciri khas bangsa Indonesia. Penjenjangan kualifikasi pada KKNI dengan jenjang sembilan sebagai jenjang tertinggi tidak serta-merta berarti bahwa jenjang tertinggi KKNI tersebut lebih tinggi dari jenjang kualifikasi yang berlaku di Eropa (8 jenjang) dan Hongkong (7 jenjang) atau sebaliknya lebih rendah dari jenjang kualifikasi yang berlaku di Selandia Baru (10 jenjang). Hal ini lebih tepat dimaknai bahwa jenis kualifikasi pada KKNI dirancang untuk memungkinkan setiap jenjang kualifikasinya bersesuaian dengan kebutuhan bersama antara penghasil dan pengguna lulusan, kultur pendidikan/pelatihan/kursus di Indonesia saat ini dan gelar lulusan setiap jalur pendidikan yang berlaku di Indonesia.

Berikut Penjenjangan KKNI melalui 4 jejak jalan (pathways) serta kombinasi ke-empatnya:

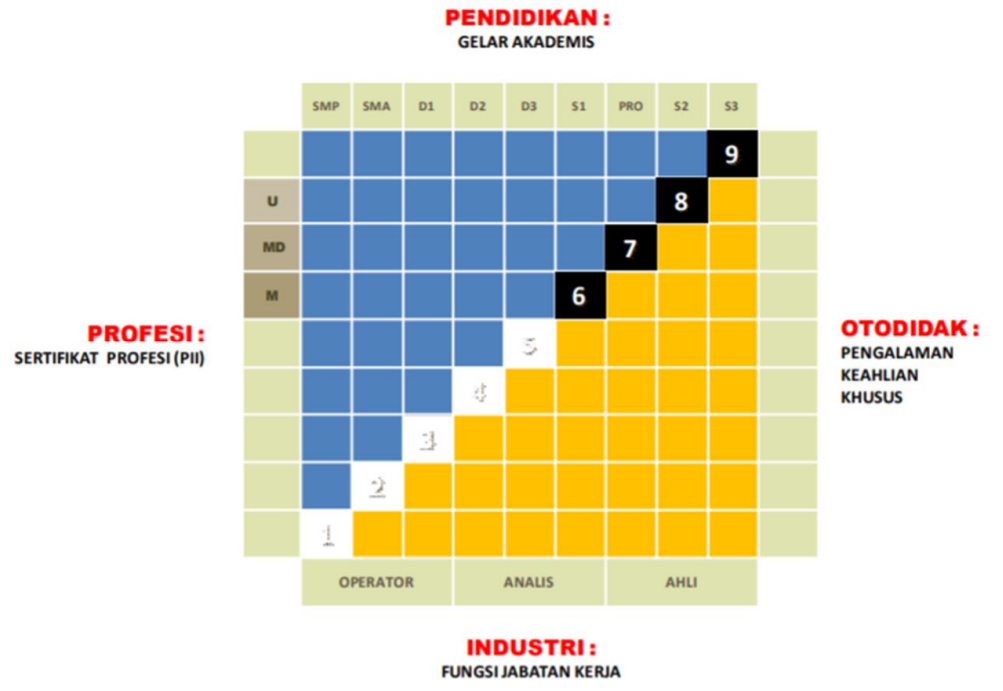

Gambar 1. Penjenjangan KKNI melalui 4 jejak jalan (pathways) serta kombinasi ke-empatnya. Sumber: Dokumen unduh 001_KKNI Kemeristekdikti (Ilustrasi oleh : Rudy Handojo - PII)

Secara konseptual, setiap jenjang kualifikasi dalam KKNI disusun oleh enam parameter utama yaitu (a) IImu pengetahuan (science), (b) pengetahuan (knowledge), (c) pengetahuan prakatis (know-how), (d) keterampilan (skill), (e) afeksi (affection) dan (f) kompetensi (competency) 2 . Ke-enam parameter yang terkandung dalam masing-masing jenjang disusun dalam bentuk deskripsi yang disebut Deskriptor Kualifikasi. Dengan demikian ke-9 jenjang kualifikasi dalam KKNI memuat deskriptor-deskriptor yang menjelaskan kemampuan di bidang kerja, lingkup kerja berdasarkan pengetahuan yang dikuasai dan kemampuan manjerial.

Uraian tentang parameter pembentuk setiap Deskriptor KKNI adalah sebagai berikut:

1. Kemampuan di bidang kerja. Komponen ini menjelaskan kemampuan seseorang yang sesuai dengan bidang kerja terkait, mampu menggunakan metode/cara yang sesuai dan mencapai hasil dengan tingkat mutu yang sesuai dan memahami kondisi atau standar proses pelaksanaan pekerjaan tersebut.

2. Lingkup kerja berdasarkan pengetahuan yang dikuasai, dimaksudkan bahwa deskriptor kualifikasi harus menjelaskan cabang keilmuan yang dikuasai seseorang dan mampu mendemonstrasikan kemampuan berdasarkan cabang ilmu yang dikuasainya tersebut.

3. Kemampuan manajerial, menunjukkan bahwa deskriptor kualifikasi harus menjelaskan lingkup tanggung jawab seseorang dan standar sikap yang dimilikinya untuk melaksanakan pekerjaan di bawah tanggung jawabnya tersebut.

Penjenjangan dalam KKNI memiliki karakteristik. dimana dalam setiap deskriptor KKNI untuk pada jenjang kualifikasi yang sama dapat mengandung atau terdiri dari komposisi unsur-unsur keilmuan (science), pengetahuan (knowledge), pemahaman (know-how atau understanding) dan keterampilan 
(skill) yang bervariasi satu dengan yang lain. Hal ini berarti pula bahwa setiap capaian pembelajaran suatu pendidikan dapat memiliki kandungan keterampilan (skill) yang lebih menonjol dibandingkan dengan keilmuan-nya (science), akan tetapi diberikan pengakuan penjenjangan kualifikasi yang setara. Karakteristik lainnya adalah jenjang kualifikasi yang semakin tinggi akan memiliki deskriptor KKNI yang semakin berkarakter keilmuan (science), sedangkan semakin rendah suatu kualifikasi akan semakin menekankan pada penguasaan keterampilan (skill).[Kemenristekdikti, 2015]

\section{Pemetaan SKKNI Kementerian Ketenagakerjaan Republik Indonesia}

Desain Grafis merupakan bidang profesi yang berkembang pesat sejak Revolusi Industri (abad ke-19) saat di mana informasi melalui berbagai media semakin luas digunakan untuk mendukung perdagangan. Bidang Desain Grafis di dunia internasional juga dikenal dengan beberapa nama lain seperti Desain Komunikasi Visual, Desain Komunikasi, Komunikasi Visual dan Komunikasi Grafis. Di Indonesia istilah yang digunakan yaitu Desain Grafis atau Desain Komunikasi Visual.

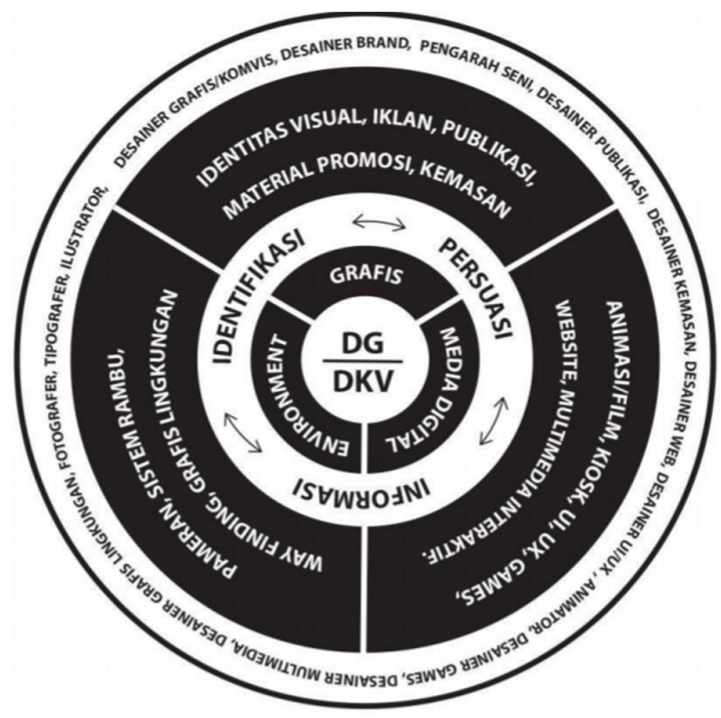

Gambar 2. Peta profesi desain grafis dan komunikasi visual berdasarkan SKKNI 2016 Sumber: [Kemenaker, 2016]

Berdasarkan peta okupasi profesi desain grafis dan komunikasi visual (SKKNI 2016). Kemudian dijabarkan secara detail berdasarkan 'Sektor/Subsektor/Area Fungsi Tujuan Utama Bisnis: Desain Grafis dan Komunikasi Visual' dengan menetapkan 'Sub-bidang/Sub-disiplin/Area Fungsi Kunci' lalu kemudian menetapkan 'Sub-bidang/Sub-disiplin/Area Fungsi mayor', sehingga detail cakupan okupasi profesi 'DG \& DKV' didetailkan pada 'Okupasi / jabatan Kerja' sebagaimana dijabarkan pada tabel 1.

\section{Kurikulum PS DKV saat ini}

Secara umum, struktur kurikulum yang terbangun saat ini masih didudukan secara umum dan menyeluruh pada wilayah cakupan dan kajian keilmuan DKV yang didominasi oleh karakter keterampilan (skill) berbobot 40\%, kemudian diikuti dengan karakter pengetahuan (knowledge) berbobot 30\%, kemudian karakter pemahaman (know-how atau understanding) berbobot $20 \%$ dan terakhir dengan karakter unsur-unsur keilmuan (science) berbobot $10 \%$.

Dengan mendudukkan komposisi bobot dengan porsi terbesar pada karakter keterampilan (skill) sebesar 40\% jika disesuaikan dengan realitas kesesuai berdasarkan acuan KKNI tentunya memberikan gambaran level KKNI berada pada posisi setara dengan level KKNI yang menjadi acuan lembaga pendidikan setara D3/D4 (level 4 dan level 5). Artinya, PS DKV yang tersebar di Indonesia saat ini dapat dikatakan memiliki kekeliruan dalam membangun struktur kurikulumnya. Sehingga terjadi ketidak sesuaian jika mengacu pada sistim penjenjangan KKNI.

Namun jika disesuaikan dengan pasar bagi lulusan, beberapa pendapat mengatakan telah sesuai dengan kebutuhan. Pendapat tersebut tentunnya ada benarnya jika berdasarkan kebutuhan industri, namun yang jadi pertanyaan adalah apakah PS DKV sebagai lembaga pendidikan yang menyiapkan Iulusan memiliki atau telah dibekali sesuai acuan KKNI dan SKNNI yang telah menjadi standar acuan 
normatif? Tentunya ini menjadi pertimbangan bagi PS DKV sebagai lembaga pendidikan tinggi untuk kembali merevisi kurikulumnya dan menyesuaikan dengan acuan yang terkini. PS DKV sebagai sumber penyedia SDM untuk memenuhi kebutuhan dunia industri, untuk itu diperlukan hubungan timbal balik antara keduanya. Dunia Pendidikan dituntut untuk mampu menyediakan SDM yang sesuai dengan kualifikasi kebutuhan industri. SDM yang berkualitas akan menjamin kesinambungan dari industri. Untuk itu diperlukan rumusan standar kualifikasi SDM yang dibutuhkan industri. PS DKV dituntut untuk dapat memenuhi standar kebutuhan kualifikasi SDM tersebut yang telah diwujudkan ke dalam Standar Kompetensi Kerja Nasional Indonesia (SKKNI) yang merupakan refleksi atas kompetensi yang diharapkan dimiliki orang-orang atau seseorang yang akan bekerja di bidang tersebut. Di samping itu, standar tersebut harus juga memiliki kesetaraan dan relevansinya terhadap standar yang berlaku pada sektor industri di negara lain, bahkan berlaku secara internasional.

Tabel 1. Uraian Okupasi/Jabatan Kerja dalam lingkup profesi DG \& DKV sesuai acuan SKKNI 2016

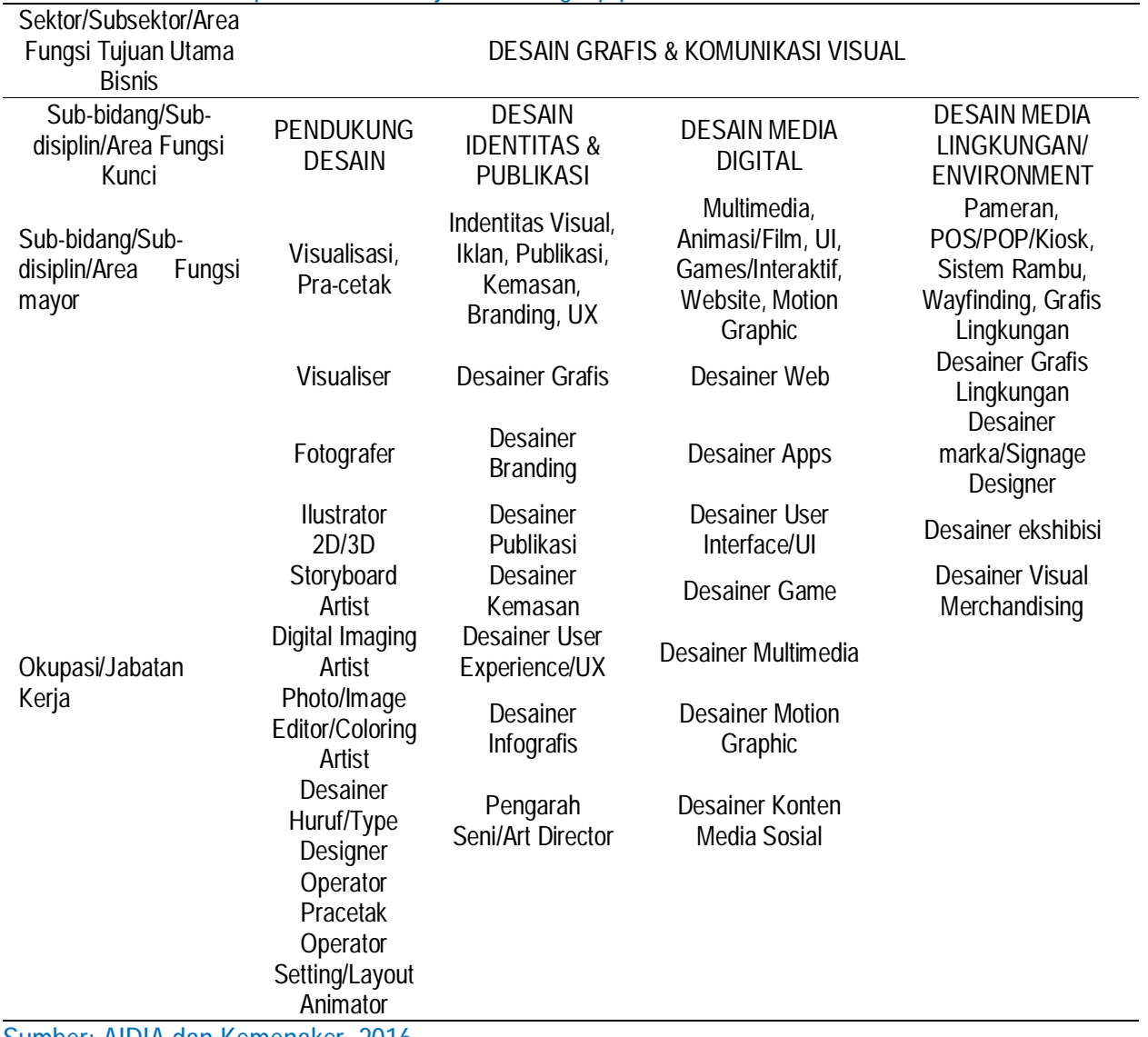

Sumber: AIDIA dan Kemenaker, 2016

Tabel 2, Tabel 3, dan Tabel 4 menunjukkan contoh pemetaan kurikulum PS DKV. Berdasarkan materi komponen mata kuliah pada sebaran pemetaan kurikulum 2008, 2012, dan 2013 yang masih digunakan, terlihat bahwa kurikulum belum dikelompokan berdasarkan konseptual parameter kualifikasi sesuai KKNI 2015, dimana setiap jenjang kualifikasi dalam KKNI disusun oleh enam parameter utama yaitu (a) IImu pengetahuan (science), (b) pengetahuan (knowledge), (c) pengetahuan prakatis (know-how), (d) keterampilan (skill), (e) afeksi (affection) dan (f) kompetensi (competency). Kurikulum tersebut masih dikelompokan berdasarkan acuan standar kurikulum lama dengan mengelompokkan berdasarkan acuan mata kuliah (makul) utama, makul pendukung dan makul umum. Berdasarkan sebaran kurikulum tercermin bobotnya yakni; a) makul utama, 36,11\%; b) makul pendukung, 56,94\%; c) makul umum, 6,94 \%. Jika pengelompokan makul dikonversikan berdasarkan parameter kurikulum berbasis KKNI 2015, maka;

- makul utama mengandung parameter; (a), (c), dan (e)

- makul pendukung mengandung parameter; (b), (c), (d), dan (f)

- makul umum mengandung parameter; (b) dan (e) 
Dari gambaran di atas diperoleh informasi bahwa kurikulum tersebut masih bersifat umum. Namun uraian di atas belum sepenuhnya akurat sebab belum terlihat pada cerminan RPSnya. Berdasarkan KKNI 2015, sebaran makul dibagi atas empat kompetensi, yakni; a) kompetensi inti; b) komepetensi pendukung; c) kompetensi pelengkap; d) kompetensi umum. Dimana pada seluruh kompetensi mengandung sebaran parameter merata pada ke-empat kompetensi.

Dari struktur bangunan kurikulum yang dibangun dapat di lihat besaran komposisi persentasi kompetensi kurikulum, jumlah mata kuliah (MK), serta besaran SKS menunjukkan bahwa kurikulum hasil work shop semester awal tahun 2012-2013 menunjang kepada upaya pembekalan kompetensi secara optimal disertai bekalan kompetensi umum yang rasio persentasi pada rancangan struktur kurikulum dinaikkan rasionya dibandingkan pemenuhan kompetensi pelengkap.

Tabel 2. Tabel kurikulum PS DKV Unika Soegijapranata

TABEL MATA KULIAH PROGRAM STUDI DESAIN KOMUNIKASI VISUAL UNIKA SOEGIJAPRANATA (KurikUlum 2008)

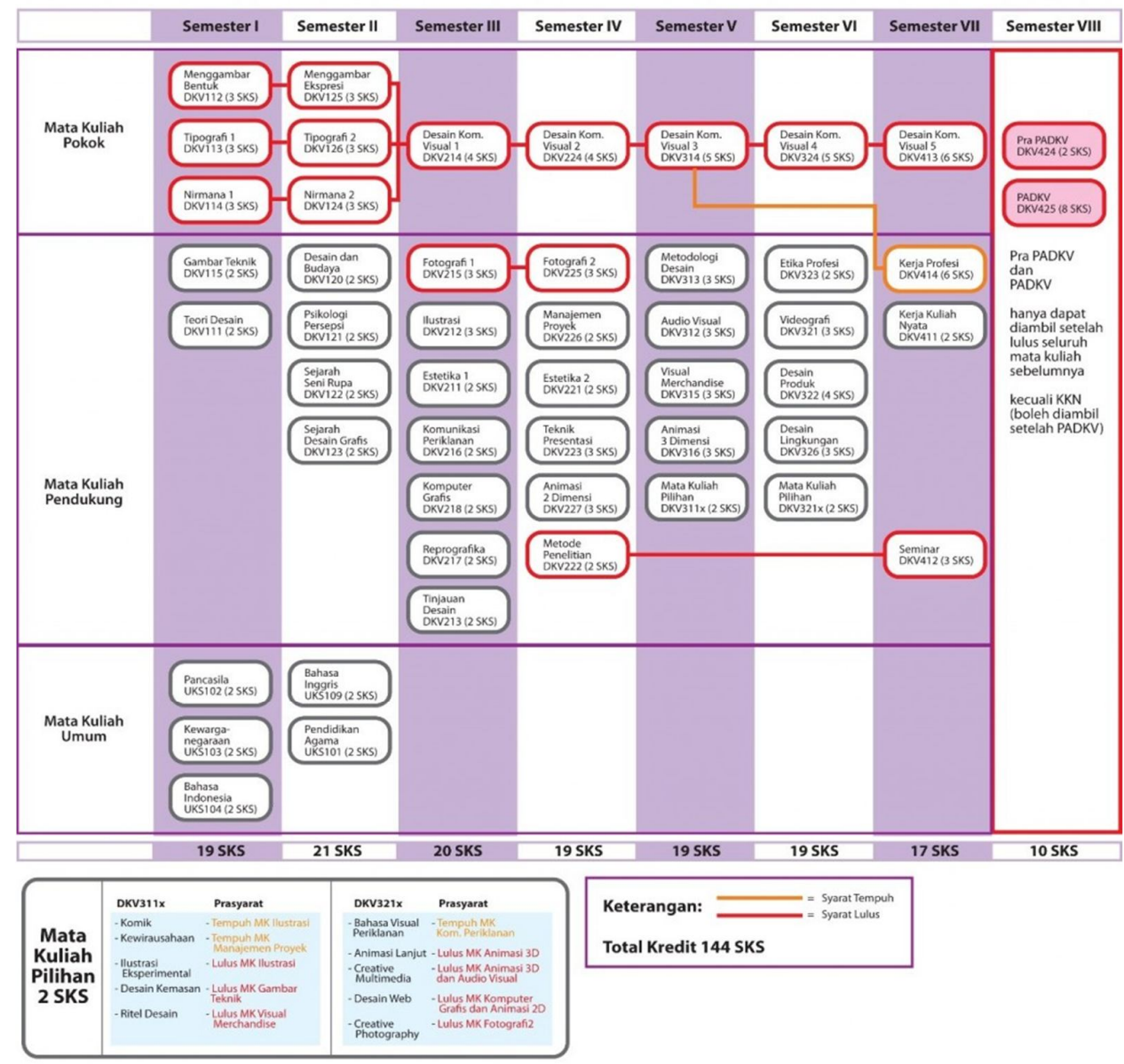

Sumber: UNIKA, 2017

Adapun maksud tujuan merubah komposisi dengan menempatkan rasio kompetensi umum lebih tinggi dibandingkan dengan kompetensi pelengkap adalah agar lulusan PS. DKV tidak hanya kompetitif pada keahlian tetapi juga kompetitif dengan bekalan wawasan, moral, sikap, dan etis secara akademik dan dalam berkehidupan, berwawawasan lingkungan dengan nilai kearifan sosial budaya konten lokal.

Pada kurikulum lama kemudian menjadi perhatian adalah pada penempatan Mata Kuliah (MK) ditempatkan secara tidak secara runtut sehingga ketika mahasiswa mengikuti program MK Komputer Grafis I semester 5, seluruh mahasiswa telah menguasai materi yang diajarkan pada MK tersebut. Idealnya, pembekalan kemampuan computer grafis diberikan di semester 3.

Acuan level kemampuan pada kurikulum lama (2010) menjadi acak sehingga tidak dapat dipastikan kemampuan dasar keahlian (manual) yang seharusnya diberikan di tahun pertama beberapa MK justru ditempatkan di tahun kedua. Dampaknya adalah pada hasil capaian pada MK tertentu tidak maksimal disebabkan pada level dasar mahasiswa belum menguasai keahlian dasar (manual). Maka pengaturan 
dan penempatan MK pada workshop ini dinyatakan perlu untuk mendapatkan perhatian agar tercipta sebuah struktur yang benar berdasarkan level tingkat pembinaan.

Berdasarkan studi pemetaan kerangka kurikulum ini pula mata kuliah yang memiliki kemiripan fungsi, tujuan, dan sasaran pembelajaran kemudian dipadatkan menjadi satu mata kuliah dan kemudian diprogramkan mata kuliah yang tepat dan sesuai berdasarkan kebutuhan standar kompetensi lulusan. Contoh, pada program mata kuliah baru Eksperimen Kreatif dipandang perlu untuk diprogramkan untuk melatih kepekaan mahasiswa pada intuisi-intuisi olah kemampuan karya kreatif yang visioner. Juga diprogrmkan mata kuliah Semantika Visual dipandang perlu untuk diprogramkan di semester 2 sebagai bekal pada kompetensi kemampuan analisa dan interpretasi tentang tanda, ikon, symbol dan lain sebagainya yang sangat berperan dan menjadi dasar bagi kemampuan kompetensi dasar perancangan deskomvis.

Tabel 3. Sebaran kurikulum PS DKV Petra 2012
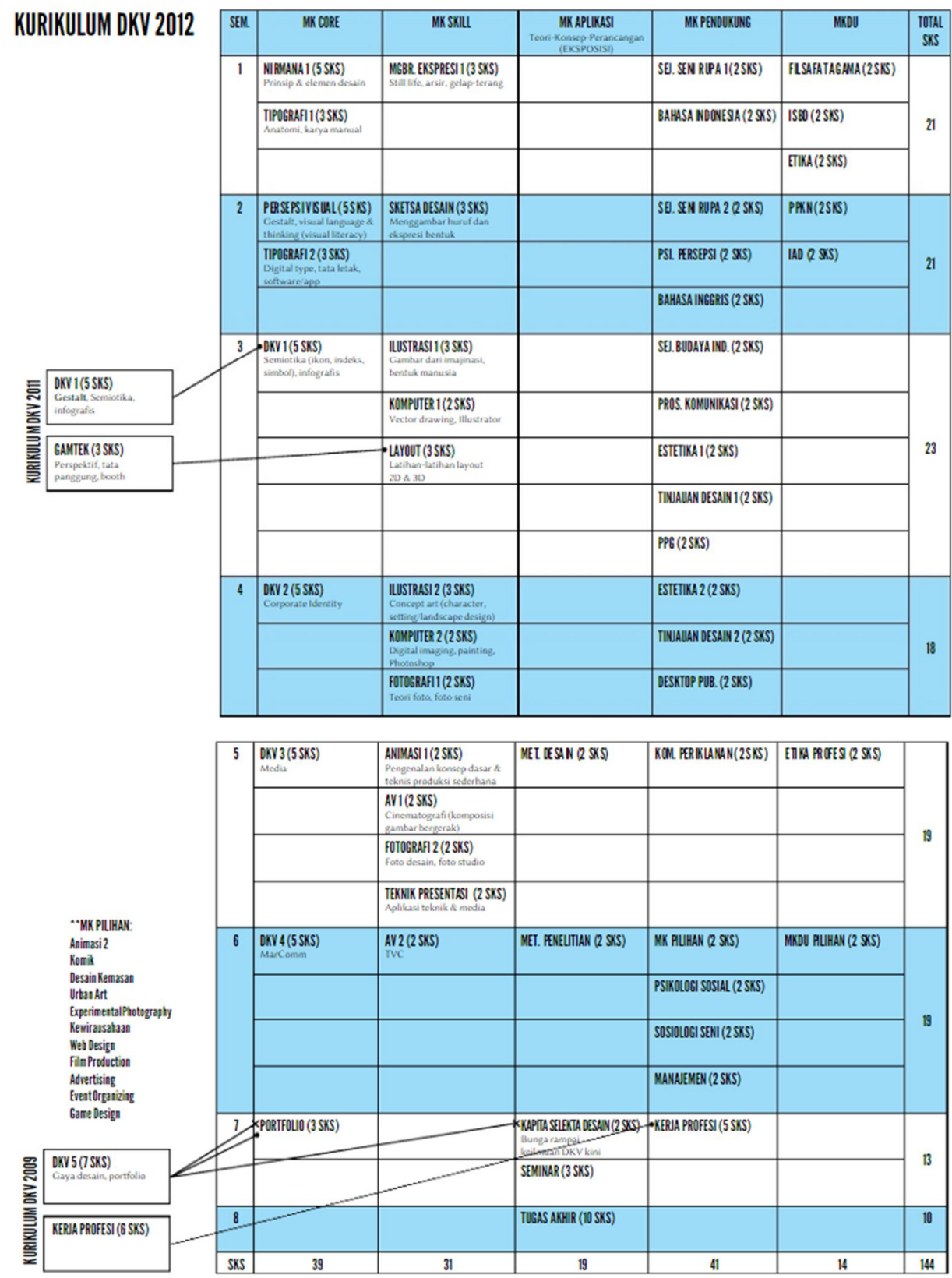

Sumber: Eko Bayu Kusumo, diupload tanggal 25 april 2013,

https://id.scribd.com/document/137947388/KURIKULUM-DKV-2012-rev3b, diakses 20 september 2017 
Tabel 4. Sebaran kurikulum PS DKV Petra 2013

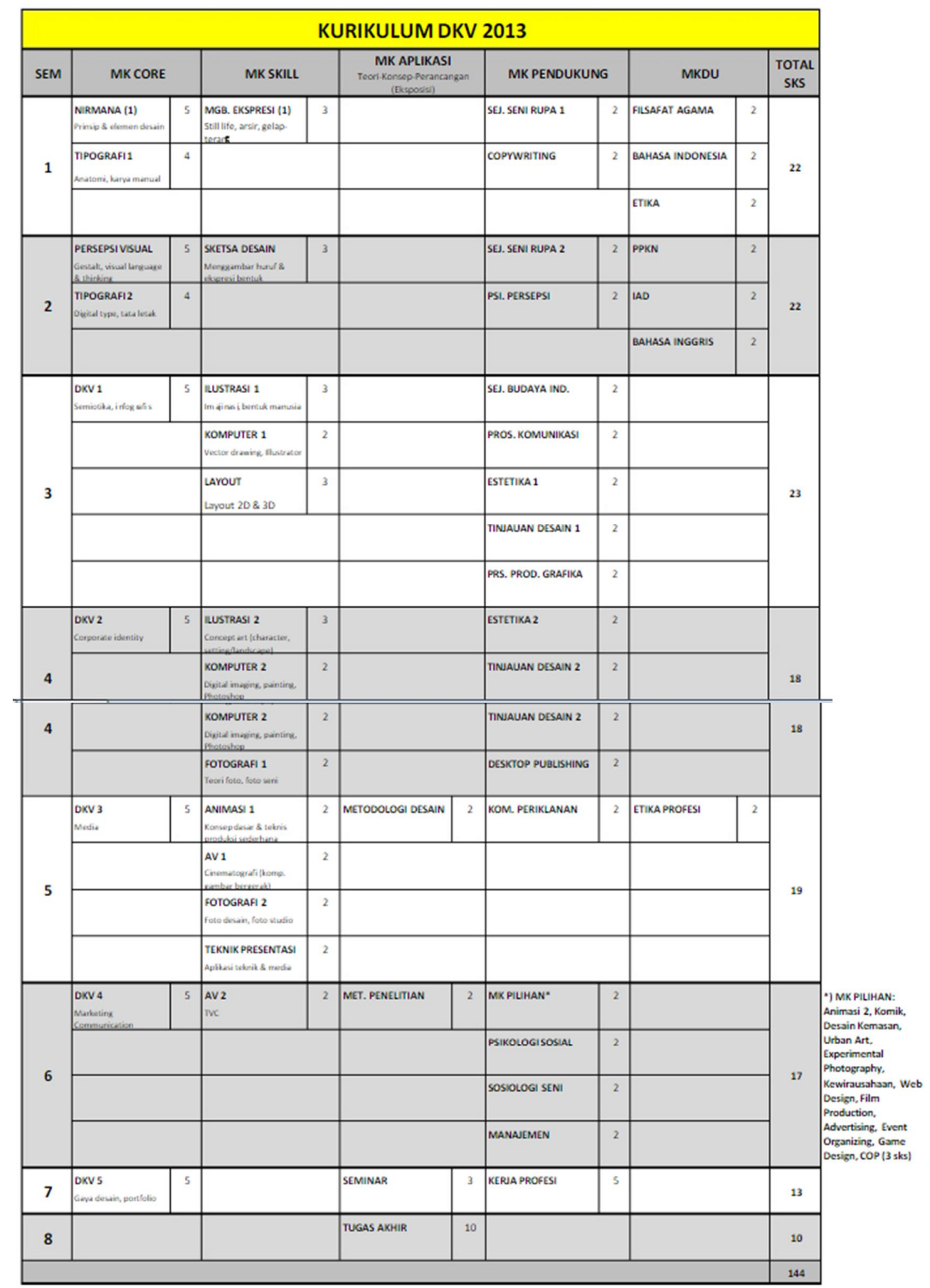

Sumber: https://id.scribd.com/document/154653795/KURIKULUM-2013, diakses 20 September 2017. 
Sebaran dan uraian kurikulum PS DKV FSD UNM

Berikut sebaran dan uraian kurikulum PS DKV UNM dijelaskan pada studi pemetaan sebagai berikut:

Tabel 5. Studi Pemetaan Kerangka Kurikulum Baru 2014

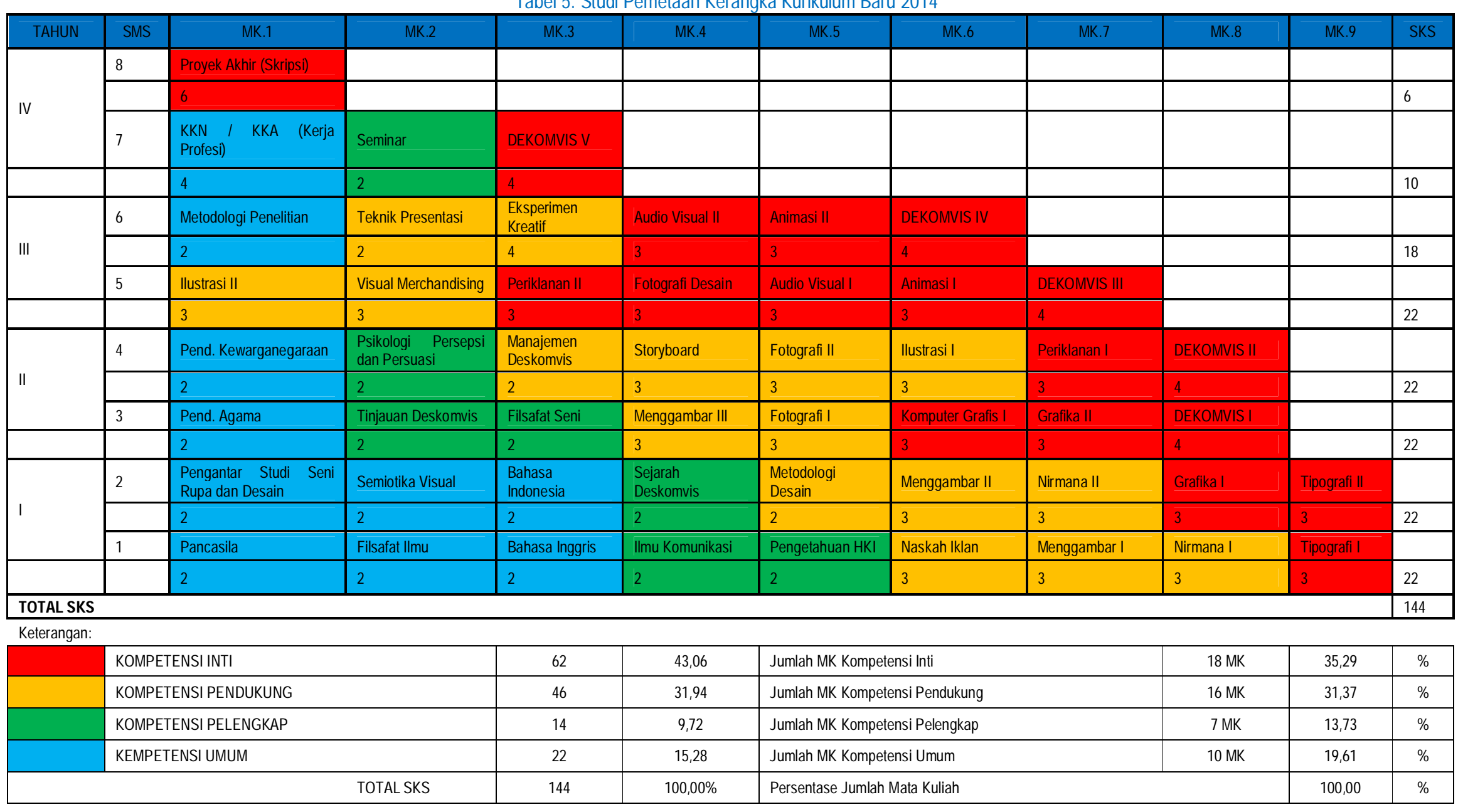

VOL. 1 NO. 1 2017, pp. 27-40, ๑ Forum Dosen Indonesia, ISSN 2580-5339 | JURNAL ANALISIS SISTEM PENDIDIKAN TINGGI | 36 


\section{Arah Pengembangan Kurikulum PS DKV}

Kurikulum PSDKV FSD UNM 2014 yang saat ini diterapkan kemudian kembali dikaji (2016-2017) untuk dipersiapkan kepada konsep kurikulum yang disesuaikan dengan acuan berbasis KKNI dan SKKNI, yakni merujuk dan mengarah pada sistim kurikulum dengan metode 'konsentrasi' yang sesuai dengan bangunan struktur;

(1) Konsentrasi Pendukung Desain, dengan sebaran area fungsi mayor Visualisasi, Pra-cetak dengan okupasi profesi sebagai; Visualiser, Fotografer, llustrator 2D/3D, Storyboard Artist, Digital Imaging Artist, Photo/Image Editor/Coloring Artist, Desainer Huruf/Type Designer, Operator Pracetak, Operator Setting/Layout, Animator

(2) Konsentrasi 'DESAIN IDENTITAS \& PUBLIKASI', dengan sebaran area fungsi mayor Indentitas Visual, Iklan, Publikasi, Kemasan, Branding, UX, dengan okupasi profesi sebagai ; Desainer Grafis, Desainer Branding, Desainer Publikasi, Desainer Kemasan, Desainer User Experience (UX), Desainer Infografis, Pengarah Seni/Art Director.

(3) Konsentrasi 'DESAIN MEDIA DIGITAL' dengan sebaran area fungsi mayor Multimedia, Animasi/Film, UI, Games/Interaktif, Website, Motion Graphic, dengan okupasi profesi sebagai ; Desainer Web, Desainer Apps, Desainer User Interface (UI), Desainer Game, Desainer Multimedia, Desainer Motion Graphic, Desainer Konten Media Sosial.

(4) Konsentrasi 'DESAIN MEDIA LINGKUNGAN/ENVIRONMENT', dengan sebaran area fungsi mayor Pameran, POS/POP/Kiosk, Sistem Rambu, Wayfinding, Grafis Lingkungan, dengan okupasi profesi sebagai; Desainer Grafis Lingkungan, Desainer marka/Signage Designer, Desainer ekshibisi, Desainer Visual Merchandising.

Perumusan materi kurikuum PS DKV di atas merupakan rujukan dari persepsi asosiasi profesi (AIDIA) yang kemudian diolah berdasarkan interpretasi dan persepsi oleh sivitas PS DKV dalam memperoleh format baku yang memeiliki relevansi terhadap potensi serapan dunia kerja baik dalam lingkup nasional maupun dalam lingkup internasional pada workshop kurikulum dalam lingkup PS DKV FSD UNM

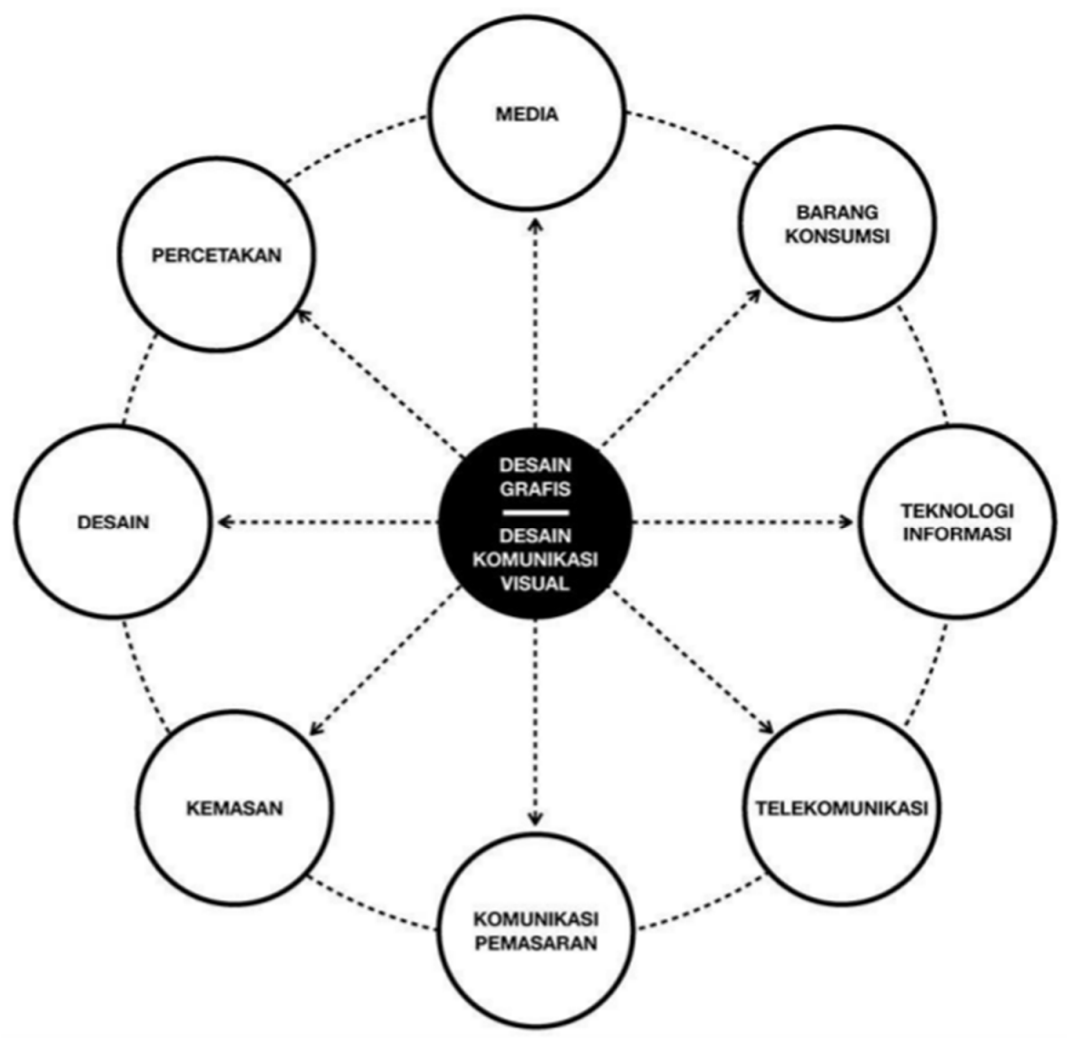

Gambar 2. Skema Peta Industri terkait bidang Desain Grafis/Desain Komunikasi Visual

Sumber: Kemenaker, 2016 
Perumusan Kurikulum berbasis rumusan kombinasi antara End User (EU), Asprodi (KKNI) dan Asprofesi (SKKNI)

\section{Peta Okupasi bidang DKV menurut EU}

Profesi DKV merupakan profesi yang memiliki irisan dengan banyak bidang, sehingga LO sangat memiliki banyak peluang untuk diserap di pasar kerja, sebagaimana dicerminkan pada gambar 2

Sayangnya, perumusan kurikulum PS DKV hingga saat ini belum menemukan sebuah format yang sinkron dengan rumusan yang dihasilkan oleh Asosiasi Profesi. Hal ini disebabkan belum terbentuknya Asosiasi Program Studi DKV yang berdiri dan telah memiliki aspek legal kelembagaan. Sehingga perumusan SKKNI bidang Desain Grafis dan Komunikasi Visual masih memiliki banyak kelemahan. Meskipun SKKNI yang dihasilkan saat ini yang dirumuskan oleh Asosiasi Profesi DG \& DKV berupaya menyesuaikan dengan pertimbangan dari aspek pendidikan.

Belum terbentuknya Asosiasi Program Studi sangat memiliki dampak bagi pemerintah untuk menentukan muatan dalam setiap level dengan kaitan lain sinkronisasi muatan level antara Learning Outcomes (LO) yang dihasilkan oleh lembaga pendidikan dengan muatan level yang ditetapkan oleh Asosiasi Profesi dalam merumuskan SKKNI untuk dijdikan rekomendasi. Dalam hal ini, pihak Asprofesi sangat berhatihati untuk menentukan mekanisme pemeringkatan dalam profesi yang dihasilkan dapat disesuaikan dengan pemeringkatan pada level KKNI yang dalam menterjemahkannya pihak Asprofesi memiliki kendala sebab mereka dituntut untuk bekerja dengan mengambil porsi yang seharusnya menjadi tanggung jawab asosiasi prodi.

\section{Perumusan SKKNI oleh Asosiasi Profesi}

Asosiasi Profesi Desain Komunikasi Visual selama ini merumuskan SKKNI selalu bersinergi dengan end user (EU) atau pengguna lulusan dan membangun komunikasi dengan asosiasi profesi lainnya yang memiliki irisan dengan PS DKV. Dalam hal ini adalah perumusan area mayor, area kunci detail jenis pekerjaan (okupasi). Tentunya dibutuhkan kualifikasi data yang valid dan berdasar dari rumusan pihak penggunan (EU).

Pada konvensi perumusan SKKNI di sektor IT Multimedia, dipetakan bahwa kedudukan Desainer Grafis Senior berada pada level $8 \mathrm{KKNI}$, ahli desain grafis (graphic designer expert) pada level 7. Jike merujuk demikian, artinya LO PS DKV adalah menghasilkan LO pada level 7, sementara jika berdasarkan KKNI yang jadi rujukan semesti berada pada level 6. Jika demikian terbukti SKKNI dan KKNI untuk PS DKV belum sinkron satu sama lainnya.

Sehingga dari permasalahan yang tampak semestinya diperlukan formulasi sebagaimana pada skema di bawah ini:

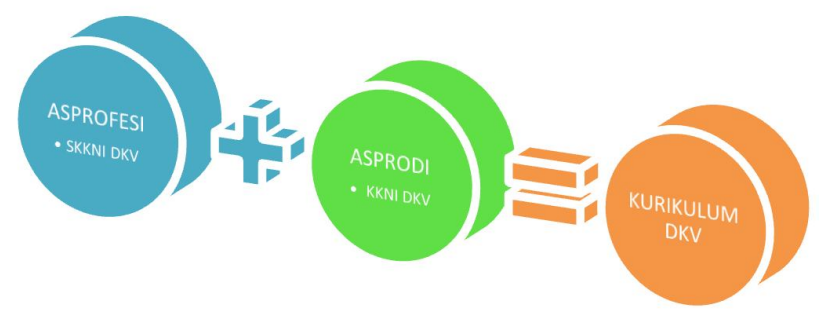

\section{Gambar 3. Skema perumusan kurikulum DKV berbasis SKKNI dan KKNI}

Oleh sebab itu, Asprodi yang telah terlembaga dan legal dari aspek hukum kelembagaan sangat urgen untuk segera diwujudkan agar segera dapat turut memikirkan peta kurikulum yang sinkron dengan pemetaan yang telah disusun oleh asprofesi dan stake-holder pengguna lulusan. Sehingga mutu LO benar-benar kompetitif dan sesuai harapan pasar. Baik pasar nasional maupun internasional.

Rumusan Konten RPS pada Kurikulum DKV

Konten materi-materi perkulihan dibangun melalui Rencana Pembelajaran semester mengacu pada hasil rumusan kajian didasarkan pada capaian hasil kajian yang diperoleh dari hasil workshop kurikulum oleh para Kajur/Sekjur dan Kaprodi/Sekprodi DKV yang berhimpun dalam wadah Asosiasi Program Studi. 
Wadah ini kemudian bertanggungjawab sebagai oraganisasi yang senantiasa memikirkan berbagai rumusan atas berbagai masalah dan upaya-upaya peningkatan manajemen kualitas mutu yang terencana, terstruktur dengan baik serta senantiasa di monitoring dan evaluasi. Sehingga seluruh program-program benar-benar mencerminkan kualitas capaian yang dapat dipertanggungjawabkan (memahami, menganalisis, dan mengevaluasi, serta kemampuan profesi desain). (lihat gambar 4 dan 5)

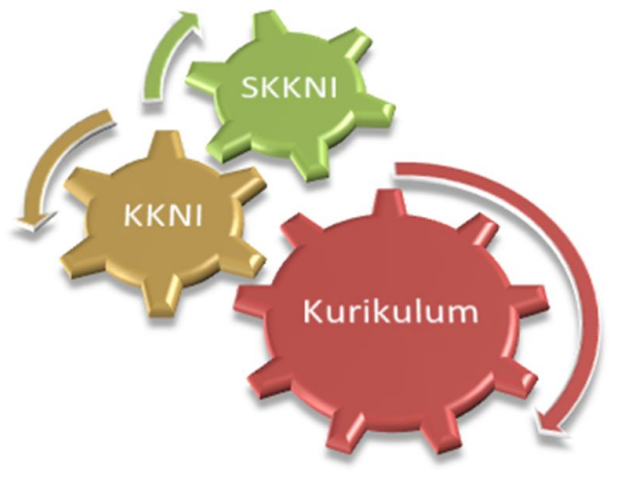

Gambar 4. Sinergi konten KKNI dan SKKNI

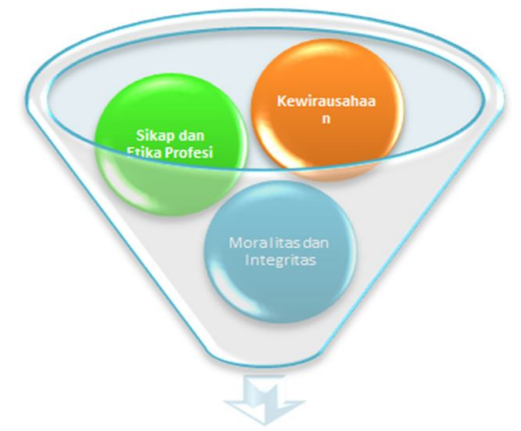

RPS

Gambar 5. Formula muatan dasar kurikulum pada perumusan RPS

Penutup

Simpulan

Merumuskan kurikulum PS DKV yang memiliki kompetensi kerja sesuai kebutuhan pengguna (End-User) dan berkemampuan adaptasi terhadap perkembangan global, dibutuhkan kehadiran lembaga-lembaga (stake-holder) perumus yang benar-benar mampu meletakkan pondasi keilmuan (KKNI) didasarkan kepada acuan kompetensi sesuai core competencies (SKKNI), yakni sinkronisasi antara rumusan asosiasi profesi dalam merumuskan SKKNI bersama Asosiasi Prodi DKV dan rumusan Asosiasi Prodi DKV dalam merumuskan KKNI PS DKV bersama Asosiasi Profesi. Sehinggadiharapka dapat dihasilkan suatu rancangan struktur kurikulum yang sangat adaptif oleh perkembangan global dan sangat dibutuhkan oleh pasar, diasmping menghasilkan LO yang memiliki potensi enterpreneurship yang berdaya saing tinggi baik dilevel nasional maupun dilevel internasional.

\section{Daftar Pustaka}

Cooper., Donald R. and chindler., Pamela S. 2003. Business Research Methods. Boston: International edition. Mc Graw Hill

Ikhsan, Maulana. 2017. Perkembangan Teknologi Informasi. http://maulsan.blogspot.co.id. [Online] 43 , 2016. [Cited: 9 19, 2017.] http://maulsan.blogspot.co.id/2016/04/perkembangan-teknologiinformasi-yang.html 
Kemenristekdikti, 2015. KERANGKA KUALIFIKASI NASIONAL INDONESIA: Dokumen 001. Jakarta: Kemenristekdikti,

KUWADO, FABIAN JANUARIUS. 2017. Jokowi Kenapa Tidak Ada Fakultas Animasi Jurusan Meme. http://nasional.kompas.com/. [Online] $8 \quad 9, \quad 2017 . \quad$ [Cited: 9 19, 2017.] http://nasional.kompas.com/read/2017/08/09/22024441/jokowi--kenapa-tidak-ada-fakultasanimasi-jurusan-meme--

Kemenaker, 2016. SKKNI, Tim Pengembang. Kepmen Ketenagakerjaan Republik Indonesia Nomor 301 Tahun 2016, tentang penetapan Standar Kompetensi Kerja Nasional Indonesia (SKKNI) kategori aktivitas profesional, ilmiah dan teknis lainya bidang Desain Grafis dan Komunikasi Visual. Jakarta : Kementerian Ketenaga Kerjaan Republik Indonesia,

[Online] http://akademik.unika.ac.id. [Online] [Cited: 9 20, 2017.] http://akademik.unika.ac.id/dkv/matakuliah/ 